\title{
Pentaerythritol Tetranitrate
}

National Cancer Institute

\section{Source}

National Cancer Institute. Pentaerythritol Tetranitrate. NCI Thesaurus. Code C47660.

The lipid soluble polyol ester of nitric acid belonging to the family of nitrovasodilators that exhibit vasodilatory property. Pentaerythritol tetranitrate releases free nitric oxide (NO) after denitration reaction, which triggers NO-dependent signaling transduction involving soluble guanylate cyclase (sGC). NO binds reversibly to the ferrous-heme center of sGC, thereby causes conformational change and activates the enzyme. Activation results in increasing cellular levels of cyclic guanosine monophosphate (cGMP) within vascular smooth muscle, which results in vasodilation mediated by cGMP-dependent protein kinases. Furthermore, this agent causes arterial and venous bed dilation in a dosedependent manner. 